\title{
DROGA DO DIGITALIZACJI AKT TOWARZYSTWA NAUKOWEGO KRAKOWSKIEGO W ARCHIWUM NAUKI PAN I PAU
}

„Więź z przeszłością musi wynikać - jeśli ma być żywa i bezpośrednia z kontaktu z oryginałem: słowem czy obrazem". Oczywiste stwierdzenie Piotra Hübnera we wprowadzeniu do publikacji źródłowej Od Towarzystwa Naukowego Krakowskiego do Polskiej Akademii Umiejętności ${ }^{1}$, prezentującej zapomniane teksty jubileuszowe, pisane z okazji 25-, 50-, 60.-lecia Akademii, jak również ukazującej ciągłość tradycji i drogę akademizacji, ma szczególny wyraz, kiedy znajdujemy się w roku jubileuszowym dwóchsetlecia Towarzystwa Naukowego Krakowskiego. Dla potrzeb niniejszego tekstu zdanie to ma szczególne znaczenie, bowiem realizowane od ponad pół wieku działania archiwistów i bibliotekarzy zmierzają do jak najpełniejszego udostępnienia spuścizny archiwalnej Towarzystwa badaczom, a obecnie w formie cyfrowej jak najszerszemu kręgowi odbiorców.

Zachowany niemal w całości materiał archiwalny jednego z pierwszych towarzystw naukowych na ziemiach polskich, którego kancelaria funkcjonowała zgodnie z zasadami systemu kancelaryjnego austriackiego, z racji swojej kompletności, należy do unikatowych zespołów archiwalnych. Skrupulatnie prowadzone dzienniki podawcze, spisywane księgi protokołów, akta komisji, czy też akta majątkowo-finansowe pozwalają odtworzyć historię miłośnictwa nauki i drogi do akademizacji stowarzyszenia, którego szczytne cele i mozolna ich realizacja dokonywała się w burzliwych czasach zaborów. Mają one szczególną wartość w sytuacji, kiedy akta innych towarzystw, działających w tym czasie, zachowały się bądź w formie szczątkowej lub uległy zniszczeniu, jak np. akta Towarzystwa Naukowego Warszawskiego, czy Towarzystwa Przyjaciół Nauk w Poznaniu.

${ }^{1}$ P. Hübner, Od Towarzystwa Naukowego Krakowskiego do Polskiej Akademii Umiejętności. Refleksje jubileuszowe Mieczystawa Offmańskiego, Tadeusza Sinki, Stanisława Wróblewskiego, Stanistawa Kutrzeby, Studia i materiały do dziejów Polskiej Akademii Umiejętności, t. I, Kraków 2002, s. 7. 
Dzieje archiwum Towarzystwa ściśle splatają się z losami biblioteki, z sukcesją ich obu na rzecz Akademii Umiejętności, z burzliwą historią Polskiej Akademii Umiejętności i dramatycznym zawieszeniem jej działalności w 1952 r., wskutek powołania do życia Polskiej Akademii Nauk. Akta Towarzystwa przechowywane od 1936 r. w Bibliotece PAU, wraz z utworzeniem w 1955 r. Oddziału Archiwum PAN w Krakowie - łącznie z całym zasobem Archiwum PAU - dały początek nowo utworzonej strukturze ${ }^{2}$.

Pierwsze prace zmierzające $\mathrm{w}$ kierunku udostępnienia i zabezpieczenia materiałów archiwalnych Towarzystwa były prowadzone w latach 50 . XX w. jeszcze w Archiwum Polskiej Akademii Umiejętności przez dr Danutę Rederową, uczennicę historyka profesora Jana Dąbrowskiego sekretarza generalnego PAU. Kontynuowane przez nią w następnych latach, kiedy kierowała krakowskim Oddziałem Archiwum PAN, zostały uwieńczone drukiem inwentarza akt, który nadal stanowi jedyną pomoc archiwalną dla korzystających, zawierającą bardzo ogólny opis bogatej i różnorodnej zawartości materiałów tego zespołu akt ${ }^{3}$. Autorka informowała odbiorcę, że, z racji ścisłego związku Towarzystwa z Uniwersytetem Jagiellońskim, od momentu powołania w 1815 do 1848 r., część akt znalazła się w Archiwum UJ, a wraz ze spuścizną Michała Zieleniewskiego sekretarza Komisji Balneologicznej TNK - w Zbiorach Specjalnych Biblioteki Jagiellońskiej. Warto tutaj dodać, że przy wydzielaniu materiałów Archiwum PAU z Biblioteki PAN do Oddziału Archiwum PAN w Krakowie pewna część zespołu akt pozostała w Bibliotece, a o tym autorka inwentarza nie wspomniała.

Szczególne zainteresowanie materiałami Towarzystwa wiązało się z podjętymi przez Bibliotekę PAU, a później po wcieleniu jej do Polskiej Akademii Nauk, Bibliotekę PAN badaniami nad dziejami ośrodka naukowego krakowskiego, a w nich dziejami Towarzystwa ${ }^{4}$. Zaowocowało to licznymi publikacjami, wśród nich sporo pozycji wyszło spod pióra Danuty Rederowej, ale także wielu pracowników Biblioteki. Dużo artykułów ukazało się na łamach „Rocznika Biblioteki PAN w Krakowie", co pokazuje wydana w r. 2006 publikacja pt. Wydawnictwa Biblioteki 1856-2006. Bibliografia (oprac. Małgorzata Kremer i Anna Sroka) ${ }^{5}$.

Na ten okres przypadają również działania mające na celu zabezpieczenie materiałów archiwalnych poprzez ich mikrofilmowanie. W czasie prac nad inwentarzem TNK zostały wykonane i włączone do zespołu mikrofilmy akt znajdujących się

${ }^{2}$ R. Majkowska, Archiwum Nauki i Biblioteka Naukowa. Kilka kart z wspólnej przeszłości... „Rocznik Biblioteki Naukowej PAU i PAN w Krakowie”, t. LI, Kraków 2006, s. 479-503.

${ }^{3}$ Inwentarz Archiwum Towarzystwa Naukowego Krakowskiego (1815-1872), oprac. D. Rederowa, Kraków 1959.

${ }^{4}$ R. Majkowska, Archiwum Nauki i Biblioteka Naukowa. Kilka kart z wspólnej przeszłości... s. 498 i n.

${ }^{5}$ Wydawnictwa Biblioteki 1856-2006. Bibliografia, oprac. M. Kremer, A. Sroka, Kraków 2006; zob. też K. Stachowska, Rocznik Biblioteki Polskiej Akademii Naukw Krakowie 1955-1974. Bibliografia zawartości i wykaz materiałów ilustracyjnych, Rocznik Biblioteki PAN w Krakowie, R. XX: 1974, s. 47-48. 
w zbiorach Archiwum UJ i Biblioteki Jagiellońskiej, a w opisie jednostki inwentarzowej umieszczono informacje o ich sygnaturach. Kolejne mikrofilmowanie akt Towarzystwa miało miejsce w ramach szerszego programu mikrofilmowania zabezpieczającego, realizowanego przez Archiwum PAN w Warszawie ${ }^{6}$.

Jak zaznaczyła we wstępie do inwentarza Danuta Rederowa, zespół akt TNK liczył wówczas 83 jednostki archiwalne oraz $2 \mathrm{mb}$ akt. Prowadzone w latach późniejszych działania krakowskiego Archiwum na rzecz pozyskiwania rozproszonych materiałów archiwalnych Towarzystwa i Polskiej Akademii Umiejętności przyniosły kolejne dopływy. W roku 1982 Muzeum Archeologiczne w Krakowie przekazało pierwszą niewielką partię archiwaliów, dopełniając ją w 1986 r. aktami Oddziału Archeologii i Sztuk Pięknych. W tym samym roku wpłynęły akta Komisji Balneologicznej, przejęte z Zakładu Zoologii Systematycznej PAN. W ten sposób powiększył się metraż zespołu akt o ok. $1 \mathrm{mb} .^{7}$

Nowe możliwości zabezpieczania i udostępniania materiałów archiwalnych otworzyły się na przełomie XX i XXI wieku wraz z „rewolucją informatyczną”. Był to czas ważnych zmian organizacyjnych krakowskiego Archiwum, w rezultacie których zostało utworzone w 2002 r. Archiwum Nauki PAN i PAU, jako wspólna jednostka Polskiej Akademii Nauk i Polskiej Akademii Umiejętności ${ }^{8}$.

Archiwum Nauki wówczas, dzięki korzystnym możliwościom inwestycyjnym, wyposażone w podstawowy sprzęt, podjęło skromny program zabezpieczania swoich zbiorów w formie cyfrowej. W ramach tego zamierzenia rozpoczęto systematyczne katalogowanie i skanowanie fotografii ze spuścizn uczonych oraz wdrożono program prac, przygotowujący najstarszy i unikatowy zespół akt Towarzystwa Naukowego Krakowskiego (1815-1872) do digitalizacji. W 2006 roku na posiedzeniu Komisji Metodycznej Archiwum Nauki został wytyczony i przyjęty program przedsięwzięcia. Opracowany harmonogram przewidywał zmianę konstrukcji inwentarza, nowy podział jednostek archiwalnych, meliorację oraz porządkowanie dopływów materiałów archiwalnych, które dotąd były tylko wstępnie usystematyzowane. Trwający remont kamienicy przy ul. Św. Jana 26, siedziby Archiwum Nauki, połączony z adaptacją strychu na pracownie, wstrzymał realizację programu. Prace wznowiono w latach 2008-2009. Tempo ich musiało być dostosowane do założeń szerokiego rocznego planu pracy Archiwum Nauki, wyniki zatem były niezadowalające. Zakończono jedynie prace nad przygotowaniem 21 ksiąg do skanowania, w tym protokoły posiedzeń prywatnych i publicznych, dzienniki podawcze, księgi finansowe. Zostały one przygotowane pod kątem merytorycznym, opracowane

${ }^{6}$ H. Zubala, Organizacja pracy w Dziale Mikrofilmów, Fotokopii i Fotografii Archiwum PAN, „Biuletyn Archiwum PAN” Nr 7, Warszawa 1964, s. 14-30; Taż, Mikrofilmowanie zbiorów archiwalnych i bibliotecznych $w$ Polsce 1950-1970. Zarys rozwoju, stan, perspektywy, Wrocław 1978, s. 95, 113, 140. Mikrofilmy do dziś służą korzystającym z Pracowni Naukowej Archiwum Nauki.

7 Akta własne Archiwum Nauki, Księga nabytków Oddziału Archiwum PAN w Krakowie z lat 1972-2001, nr 129, 205, 206.

${ }^{8}$ T. Skrzyński, Archiwum Nauki Polskiej Akademii Nauk i Polskiej Akademii Umiejętności. Z przeszłości i teraźniejszości..., Kraków 2008, s 7-8. 
i sfoliowane. Kopie cyfrowe wykonała firma Digital Center, Mikrofilm Center systemy archiwizacji dokumentów. Materiały te zostały również poddane konserwacji.

Przed zespołem archiwistów pracujących nad koncepcją nowego kształtu inwentarza pojawiło się pytanie - jaka jego forma będzie dostępna najszerszemu kręgowi odbiorców z równoczesną pełną ochroną oryginałów? Stąd zrodził się w 2012 r. pomysł stworzenia inwentarza interaktywnego, udostępnionego on-line.

Z myślą o zbliżającym się w 2015 roku jubileuszu dwóchsetlecia Towarzystwa Naukowego Krakowskiego, o konieczności rozłożenia prac na kolejne lata, podjęto próbę ubiegania się o trzyletni grant, pod patronatem Polskiej Akademii Umiejętności, w Narodowym Centrum Nauki w Krakowie. Pierwszy wniosek został złożony w 2012 r. w programie „Opus”, ponowny w 2013 roku. Oceny merytoryczne projektu brzmiały: „Badania zaplanowane w ramach realizacji projektu gwarantują nie tylko uzupełnienie wiedzy historycznej o cenne dane z działalności TNK, ale również przedstawienie rezultatów trzyletnich prac w nowoczesnej formie cyfrowej/interaktywnej. Jest to więc cenna inicjatywa badawcza, a równocześnie w przystępny i atrakcyjny sposób popularyzująca wiedzę historyczną. Problematyzuje przy tym działalność Towarzystwa w odniesieniu do miejsca nauki w rzeczywistości Polski w okresie zaborów” (ekspert 1); „Opracowywanie inwentarzy archiwalnych, skorowidzów czy innych pomocy naukowych jest jedną z podstaw rozwoju badań naukowych. Projekt opracowania inwentarza akt Towarzystwa Naukowego Krakowskiego zasługuje na uznanie”. (ekspert 2). Przy podkreśleniu mocnych stron wniosku stwierdzono: ,Wniosek jest przejrzysty, a jego realizacja nie tylko uzasadniona, zwłaszcza przy okazji zbliżającego się jubileuszu TNK, ale wręcz niezbędna z uwagi na możliwość bezpowrotnej utraty niszczejących archiwaliów [...] Na znaczeniu projekt zyskuje także dzięki planowi realizacji badań na szeroką skalę, a więc nie tylko w Krakowie, lecz w innych ośrodkach polskich i zagranicznych. Na uznanie zasługuje także oryginalne podejście do pracy archiwalnej i nacisk położony na udostępnienie rezultatów badań w nowatorskiej, cyfrowej i interaktywnej formie, dostępnej nie tylko badaczom, ale również łatwiejszą do popularyzacji w szerszym gronie odbiorców". Niestety w obu przypadkach nie zakwalifikowano wniosku do drugiego etapu oceny merytorycznej. To był marzec 2014 roku.

Archiwiści z Archiwum Nauki nie zrezygnowali jednak z dążenia do celu. Cały czas trwają prace archiwalne nad aktami luźnymi, wśród nich nad korespondencją, aktami Wydziałów, Oddziałów - bogatą dokumentacją Oddziału Archeologii i Sztuk Pięknych oraz komisji takich, jak: Komisja Fizjograficzna, Balneologiczna, Historyczna. Po ich sfoliowaniu zostaną zeskanowane. Prowadzone są też kwerendy w Archiwum UJ, w zbiorach Biblioteki Naukowej PAU i PAN w Krakowie i Biblioteki Jagiellońskiej, z myślą o zeskanowaniu materiałów stanowiących część rozproszoną tego zespołu archiwalnego, rozproszoną z powodu istniejącego u początku działalności Towarzystwa ścisłego związku z Uniwersytetem Krakowskim, a także wynikłe z uwarunkowań historycznych.

Równocześnie we współpracy z informatykiem powstaje projekt interaktywnego inwentarza z bazą danych, m.in. o członkach Towarzystwa. W dalszym per- 
spektywie przewidziany jest dostęp on-line do poszczególnych stron w jednostkach archiwalnych. Pozwoli to na pokazanie więzi z przeszłością „słowem i obrazem”.

Niestety przygotowywana $\mathrm{w}$ ramach grantu szeroka kwerenda w kraju i za granicą, pokazująca miejsce Towarzystwa Krakowskiego wśród towarzystw o podobnym charakterze, jak np. czeskie Królewskie Towarzystwo Naukowe, jak też mająca ujawnić rozproszenie materiałów Towarzystwa - tak cennego źródła do historii nauki - musiała być ograniczona i częściowo odłożona na przyszłość.

Planowane przez Archiwum Nauki na czas jubileuszu wystawy oraz konferencja organizowana przez Polską Akademię Umiejętności 9-10 grudnia 2015 roku będą czasem przybliżenia działalności tej tak ważnej dla historii instytucji, a dla członków Akademii Umiejętności przypomnieniem powrotu do korzeni. Bo jak w wielu miejscach swoich prac podkreśla Piotr Hübner: „Tradycję stanowiło też to, co w materialnej postaci - ale mającej przede wszystkim wymiar duchowy - przekazało Towarzystwo powołanej zeń Akademii. [...] Przede wszystkim jednak odziedziczyła Akademia dorobek naukowy i doświadczenia organizacyjne Towarzystwa, także te z okresu wymuszonych bezczynności"

\section{RITA MAJKOWSKA}

\section{THE WAY TO DIGITIZATION OF THE FILES OF THE CRACOW SCIENTIFIC SOCIETY IN THE ARCHIVE OF SCIENCE OF POLISH ACADEMY OF SCIENCES AND THE POLISH ACADEMY OF ARTS AND SCIENCES IN CRACOW}

\section{Summary}

December 2015 marks the $200^{\text {th }}$ anniversary of the foundation of Cracow Scientific Society. Adopted by the Board of Rectors of Cracow Academy, the first statute of the Society, closely connected with the university in the early stages of its existence, was approved 200 years ago - on the $9^{\text {th }}$ of December 1815 by the authorities of the Republic of Cracow. Kept in the Archive of Science of Polish Academy of Sciences and Polish Academy of Arts and Sciences in Cracow, preserved almost intact, the archival material of one of the first scientific societies founded on Polish lands, due to its completeness, constitutes a unique fonds. Thus, the objective of the actions of the archivists, initiated over 50 years ago, has been to grant the researchers the fullest possible access to the archival legacy of the Society, and now in a digital form on-line share it with the broadest possible circle of recipients. At the same time, due to the digitization programme (combined with the conservation) it will be possible to prevent these precious materials from deteriorating. The article describes the road from the first works of Danuta Rederowa, the author of the inventory of the records of the Society, to the ongoing actions to digitize the unique archival materials and create a new version of the inventory in a digital form.

\footnotetext{
${ }^{9}$ P. Hübner, Od Towarzystwa Naukowego Krakowskiego..., op. cit., s. 246-247.
} 
(C) Copyright by Polska Akademia Umiejętności \& Autorzy, Kraków 2015 